\title{
Control of Asian soybean rust with mancozeb, a multi-site fungicide
}

\author{
Luís Henrique Carregal Pereira da Silva, Hercules Diniz Campos, Juliana Resende Campos Silva e Erlei Melo \\ Reis
}

Universidade de Rio Verde - GO. OR - Melhoramento de sementes - Passo Fundo - RS

Autor para correspondência: Erlei Melo Reis (erleireis@upf.br)

Data de chegada: 04/12/2013. Aceito para publicação em: 16/01/2015.

$10.1590 / 0100-5405 / 1957$

\section{RESUMO}

Silva, L. H. C. P.; Campos, H. D.; Silva, J. R. C.; Reis, E. M. Controle da ferrugem asiática da soja com mancozebe um fungicida multissítio. Summa Phytopathologica, v.41, n.1, p.64-67, 2015.

Em experimento conduzido no campo testou-se a ação do mancozebe, fungicida de ação multissítio, no controle da ferrugem da soja causada por Phakopsora pachyrhizi. Sua ação foi comparada à mistura ciproconazol (IDM) + azoxistrobina (IQe). Utilizou-se a cultivar de soja NA 7337 RR com uma população de 400.000 plantas/ha cultivada em parcelas de $20 \mathrm{~m}^{2}$. Os tratamentos constaram de doses do mancozebe (1,5 e 2,0 kg/ha) aplicados quatro, seis e oito vezes. A mistura de IDM + IQe foi aplicada três vezes a $0,3 \mathrm{~L} / \mathrm{ha}+$ Nímbus. Avaliou-se a severidade da ferrugem nas parcelas em seis momentos e os dados foram integralizados como área abaixo da curva de progresso da doença (AACPD). As parcelas foram colhidas e o rendimento de grãos expresso em $\mathrm{kg} / \mathrm{ha}$. Os dados da AACPD e do rendimento foram submetidos a análise de variância e as médias comparadas pelo teste de Tukey $(\mathrm{p}=0.005)$. Os tratamentos com mancozebe foram superiores à mistura IDM + IQe, tanto no controle da ferrugem, como no rendimento de grãos. Quatro aplicações de $2.0 \mathrm{k} / \mathrm{ha}$ de mancozebe foram superiores a três aplicações da mistura usada como padrão. O mancozebe tem potencial para ser adicionado às misturas de fungicidas na implementação de estratégia antiresistência da ferrugem da soja.

Palavras-chave adicionais: Estratégia antiresitência, Phakopsora pachyrhizi, falha de controle, fungicida protetor.

\section{ABSTRACT}

Silva, L. H. C. P.; Campos, H. D.; Silva, J. R. C.; Reis, E. M. Control of Asian soybean rust with mancozeb, a multi-site fungicide. Summa Phytopathologica, v.41, n.1, p.64-67, 2015.

An experiment conducted in the field the action of mancozeb, a fungicide of multi-site action was tested, to control soybean rust caused by Phakopsora pachyrhizi. Its performance was compared to that of the mixture cyproconazole (DMI) + azoxystrobin (QoI). The soybean cultivar NA 7337 RR was used with a population of 400,000 plants/ha cultivated in $20 \mathrm{~m}^{2}$ plots. Treatments consisted of mancozeb levels (1.5 and $2.0 \mathrm{~kg} / \mathrm{ha})$ applied four, six and eight times. The DMI + QoI mixture was applied three times at $0.3 \mathrm{~L} / \mathrm{ha}+$ Nimbus. Rust severity was assessed six times in the plots and data were integrated as the area under the disease progress curve (AUDPC). The plots were harvested and grain yield was expressed as $\mathrm{kg} / \mathrm{ha}$. Data on AUDPC and yield were subjected to analysis of variance and means compared according to Turkey's test ( $\mathrm{p}=$ 0.005). Treatments with mancozeb were superior to DMI + QoI mixture both for rust control and grain yield. Four applications of $2.0 \mathrm{k} / \mathrm{ha}$ mancozeb were more efficient than three applications of the mixture used as standard. Mancozeb has the potential to be added to fungicide mixtures in the establishment of soybean rust anti-resistance strategy.

Additional keywords: Anti-resistance strategy, Phakopsora pachyrhizi, control failure, protectant fungicide.

Asian soybean rust (ASR), caused by Phakopsora pachyrhizi Sydow (Pp), was found in Brazil in 2002/03 and in the same season its control with fungicides started $(6,14)$. The first used chemicals belonged to the fungicides triazole or demethylation inhibitors (DMI), especially flutriafol and tebuconazole. Difenoconazole, myclobutanil and tetraconazole, single-site fungicides with the same mode of action, were also used. Subsequently, cyproconazole was used only in mixtures with QoI.

Almost all of the cultivated area (27 million hectares in the 2012/13 season) was treated with fungicide in order to control rust, reaching $93 \%$ in 2012. The highest percentage of the area has been treated with DMIs
+ QoIs (60\%). However, DMIs have been used even alone in 24\% of the area and the area treated with QoIs alone has increased, reaching $3.66 \%$ in 2012 (10). Their use alone is not recommended by FRAC (4)

After five growing seasons (from 2002/03) of use of DMI alone, Silva et al. (13) reported rust control failure in Goiás, in 2006/07, for cyproconazole, flutriafol and tebuconazole. Until then, flutriafol had been very effective and used by researchers as a standard control, making it the market leader. From 2005/06 onwards, there was a reduction in flutriafol effectiveness in Mato Grosso State, first attributing the control failure to formulation quality (5).

After the flutriafol decline, although as a DMI, tebuconazole 
became widely used with high efficiency and was adopted as a reference fungicide to control ASR.

To clarify the facts, experiments conducted at MT Foundation in Rondonópolis (5), at University of Rio Verde and other institutes, confirmed the control efficiency reduction. The latter was clearly proven when DMI performance in 2005/06 season was compared to that in the last season $(2012 / 13)$ by a study conducted at University of Rio Verde. In 2005/06 season, rust average control by DMIs was $90.3 \%$. After only eight seasons, corresponding to 2012/13, DMI control was 52.0 , showing $42 \%$ control efficacy reduction $(7,13)$. The reduction in $P p$ sensitivity to the fungicides tebuconazole and cyproconazole, with only 42 and $38 \%$ control, respectively, was also proven by Godoy $\&$ Palaver (6). In this season, DMI + QoI mixtures did not show reduced efficiency yet; cyproconazole + azoxystrobin had $72 \%$ control and pyraclostrobin + epoxyconazole, $88 \%$ control. At this time, the mean control for the mixtures was $80 \%$. It is likely that the effectiveness was ensured by QoIs, as the control mean for DMI was only $40 \%$ (6).

DMI and QoI fungicides act on only one specific site of thousands of biochemical reactions in the fungal cell. Therefore, they are vulnerable to fungal strain selection towards sensitivity reduction or loss. FRAC (4) classifies DMIs and QoIs as fungicides of high risk for the development of resistance and, therefore, do not recommend their use alone.

The difficulty in controlling ASR with fungicides is becoming increasingly evident, proving the high fungal adaptability $(1,6,7,9$, 12). As an example, tebuconazole efficiency has been gradually reduced from $90 \%$ to $24 \%$ in ten seasons (7).

Some actions should be taken to make ASR chemical control reach $80-90 \%$ efficiency again, as in 2002/03 to 2008/09 growing seasons $(6,7)$. It is necessary to develop a strategy to ensure economic control for growers to face the rust threaten.

The aim of the study was to show the fungitoxicity of mancozeb, a multi-site broad spectrum fungicide for which fungal resistant has not yet been reported, in order to fight ASR.

\section{MATERIAL AND METHODS}

The experiment was conducted at the experimental field of Agricultural Research and Agro Carregal Plant Protection Ltda in Rio Verde - GO (S17 $47^{\prime} 067$; W 51 ${ }^{\circ} 00^{\prime} 214$ and $753 \mathrm{~m}$ a.s.1.)

The transgenic soybean NA 7337 RR cultivar was used, with 400,000 plants/ha, in $4 \mathrm{~m}$ wide $\mathrm{x} 5 \mathrm{~m}$ long plots.

In the experiment, the following fungicides were tested: (i) mancozeb (Manganese ethylenebisdithiocarbamate $+\mathrm{Zn}$ ) (Unizeb Gold - United Phosphorus Ltda) $80 \%$, in the formulation of water dispersible granules (DG), at 1.5 and $2.0 \mathrm{~kg} / \mathrm{ha}$, sprayed four, six and eight times, and (ii) cyproconazole (8\%) + azoxystrobin $(20 \%) 0.3 \mathrm{~L} / \mathrm{ha}$
(Priori Xtra) + Nímbus (0.5\%), applied three times (Table 1). Fungicide treatments were sprayed with a precision knapsack sprayer of pressure generated by $\mathrm{CO}_{2}$, delivering $200 \mathrm{~L} / \mathrm{ha}$, and with a boom showing six double flat fan nozzels TJ 110.02 .

Weed and insect pest control was performed according to instructions for study of soybean crop (10).

Disease severity was assessed in leaves separately taken from the upper and lower part of the canopy, according to the diagrammatic scale developed by Canteri \& Godoy (3). Five plants per plot were randomly collected, and 10 trifoliate leaves per plot were taken from the same plant node. Disease severity was evaluated from V7 to R6 growth stage, totaling six assessments (V7, R1, R4, R5.1, R5.2 and R6).

Harvest was manually performed and grains were threshed in a stationary threshing machine, cleaned, weighed and expressed as $\mathrm{kg} / \mathrm{ha}$.

Severity data were converted into area under the disease progress curve (AUCPC), as proposed by Campbell \& Madden (2). Data on AUDPC and grain yield were subjected to analysis of variance and means compared according to Tukey's test $(p=0.005)$.

\section{RESULTS}

Considering the concern about the ASR chemical control efficiency in the past, present and future and the search for a solution to control soybean rust, the dithiocarbamate fungicide [maneb $+\mathrm{Zn}$ or mancozebe (MCZB)] (Manganes ethylenebisdithiocarbamate + Zn - MEBDC) was tested. It is a non-penetrating, non-mobile, multi-site fungicide that remains on the plant surface after application.

Regarding the AUDPC, treatment MCZB 4 (115 a) and MCZB 5 (126 a), same statistical group, were followed by MCZB 3 (126 b), MCZB 2 (205 c), C + A 6 (240 d) and control treatment with no fungicide (816 e). As regards dose and number of applications, rust control based on AUDPC was greater with EBDCM than with the DMI + QoI mixture used as standard for ASR control (Fig. 1).

The highest soybean grain yield was obtained for MCZB 5 with $3.245 \mathrm{~kg} / \mathrm{ha}$, as well for MCZB 4 with 3.215 (b) $\mathrm{kg} / \mathrm{ha}$, MCZB 4 with $3.106(\mathrm{ab})$, MCZB 2 with $3.034(\mathrm{ab}), \mathrm{C}+\mathrm{A} 6$ with 2.823 (b) and the control with 2.040 (c) kg/ha (Fig. 2).

Mancozeb is classified by the Fungicide Resistance Action Committee (FRAC)(4) into the mode-of-action group M (Multi-Site Action), a typical multi-site protectant-only fungicide.

The introduction of a multi-site fungicide in the rust control program may be an important tool for $P p$ resistance management, with the potential to preserve the life-time of site-specific (DMI, QoI and $\mathrm{SDHI}$ ) fungicides in soybean crop (4). Thus, mixtures of fungicides that combine a high resistance risk (i.e. DMI and QoI) with a low risk multi-site compound (i.e. MCZB) or another multi-site fungicide can

Table 1. Treatments, fungicide doses ( $\mathrm{kg}$ or $\mathrm{L} / \mathrm{ha}$ ) and soybean growth stages for application

\begin{tabular}{|c|c|c|c|c|c|c|c|c|}
\hline \multirow{2}{*}{ Treatments } & \multicolumn{8}{|c|}{ Growth stages } \\
\hline & V7 & $\mathrm{R} 1$ & R3 & $\mathrm{R} 4$ & R5.1 & R5.3 & R5.4 & R5.5 \\
\hline No fungicide & \multicolumn{8}{|c|}{ Control } \\
\hline $\mathrm{MCZB} 2^{\mathrm{y}}$ & 2.0 & 2.0 & 2.0 & 2.0 & - & - & - & - \\
\hline MCZB 3 & 1.5 & 1.5 & 1.5 & 1.5 & 1.5 & 1.5 & - & - \\
\hline MCZB 4 & 2.0 & 2.0 & 2.0 & 2.0 & 2.0 & 2.0 & - & - \\
\hline MCZB 5 & 1.5 & 1.5 & 1.5 & 1.5 & 1.5 & 1.5 & 1.5 & 1.5 \\
\hline $\mathrm{C}+\mathrm{A} 6^{\mathrm{z}}$ & - & 0.3 & - & 0.3 & - & 0.3 & - & - \\
\hline
\end{tabular}

$\mathrm{y}=$ mancozeb; $\mathrm{z}=$ cyproconazole + azoxystrobin. 


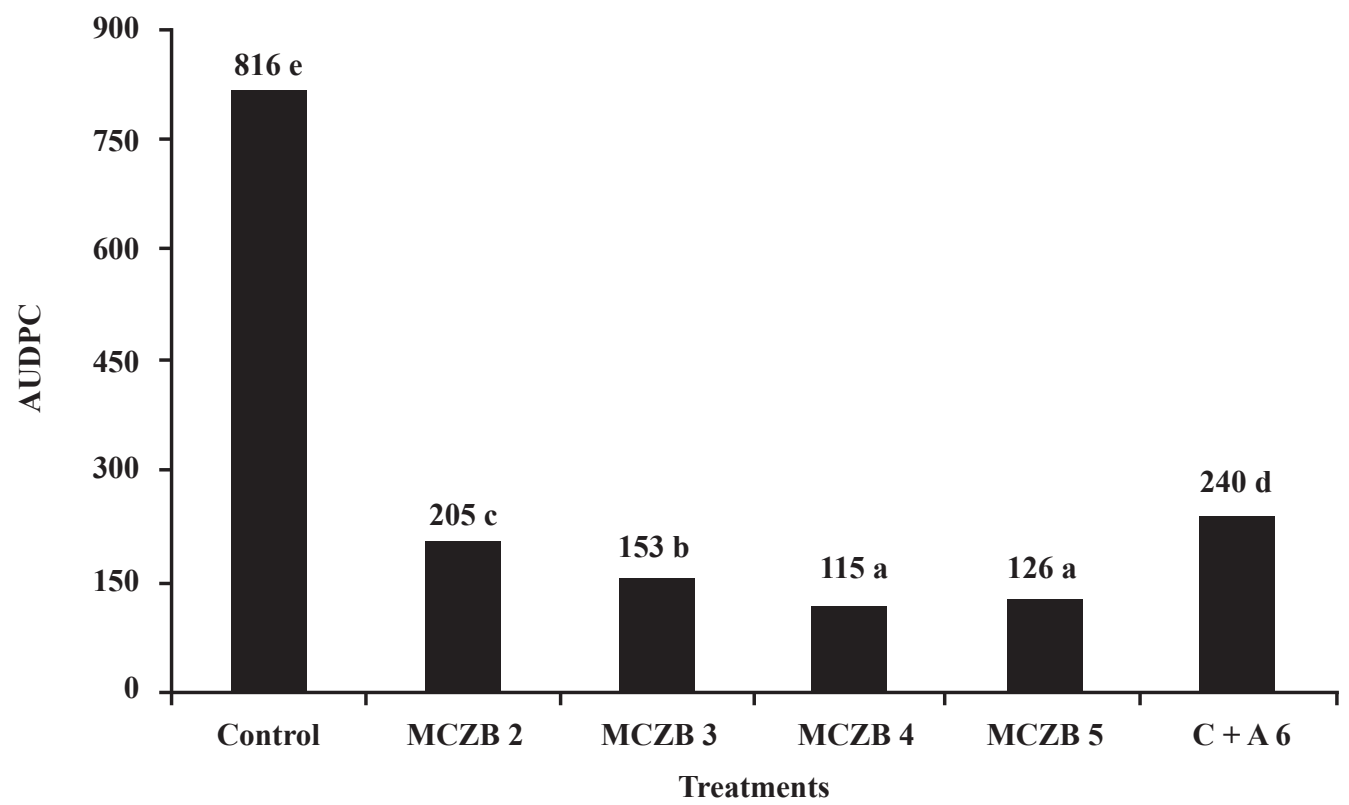

Figure 1. Soybean rust control rated by the area under the disease progress curve (AUDPC) for the treatments. Means followed by the same letter do not differ according to Turkey's test $(\mathrm{p}=0.005)$. CV $=3.32 \%$. Control; MCZB (mancozeb) $2-2.0 \mathrm{~kg} / \mathrm{ha}$ sprayed four times; MCZB 3 - $1.5 \mathrm{~kg} / \mathrm{ha}$ sprayed six times; MCZB 4 - $2.0 \mathrm{~kg} / \mathrm{ha}$ sprayed six times; MCZB 5 - $1.5 \mathrm{~kg} / \mathrm{ha}$ sprayed eight times; and C + A (Cyproconazole + Azoxystrobin) - $0.3 \mathrm{~L} /$ ha sprayed three times.

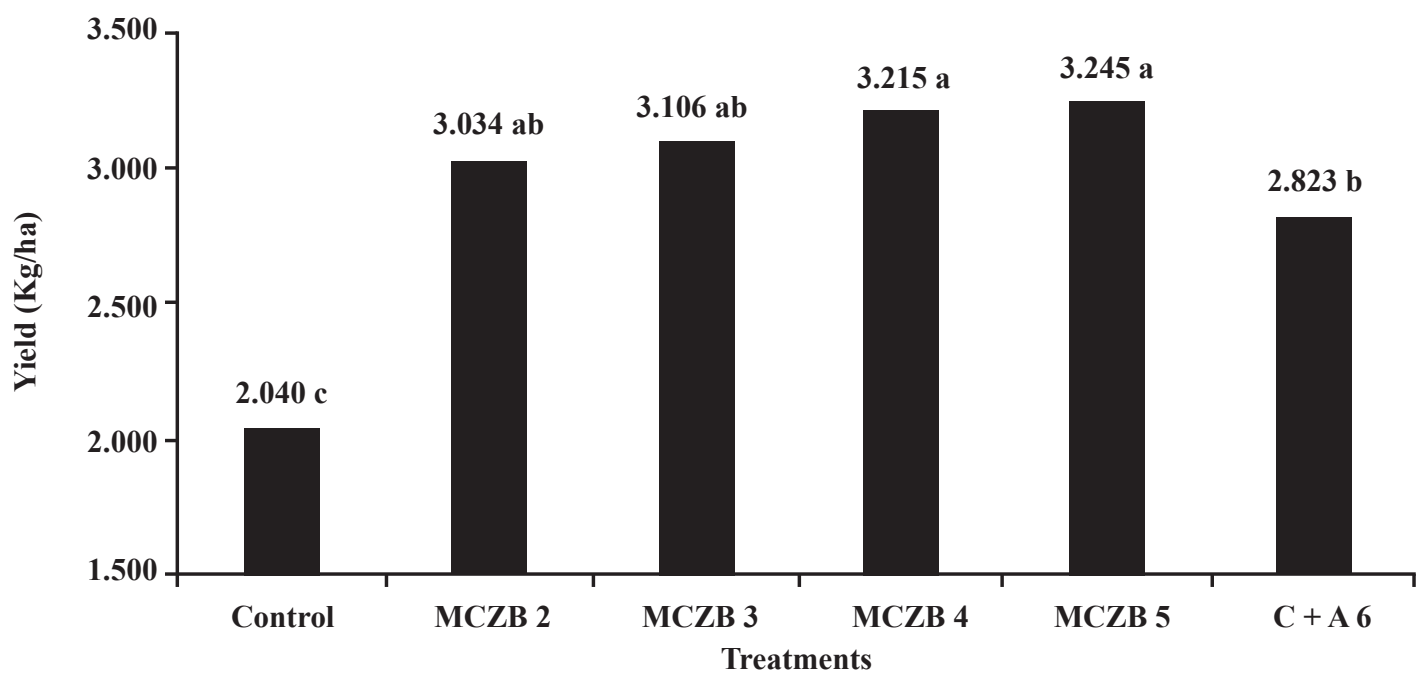

Figure 2. Effect of rust control by fungicide treatments on soybean grain yield ( $\mathrm{kg} / \mathrm{ha})$. Means followed by the same letter do not differ according to Turkey's test ( $\mathrm{p}$ $=0.005) \mathrm{CV}=5.58$. Control; MCZB (mancozeb) $2-2.0 \mathrm{~kg} / \mathrm{ha}$ sprayed four times; MCZB $3-1.5 \mathrm{~kg} / \mathrm{ha}$ sprayed six times; MCZB $4-2.0 \mathrm{~kg} / \mathrm{ha}$ sprayed six times; MCZB $5-1.5 \mathrm{~kg} / \mathrm{ha}$ sprayed eight times; and C + A (Cyproconazole + Azozystrobin) - $0.3 \mathrm{~L} / \mathrm{ha}$ sprayed three times.

be useful in the present situation of rust shift in sensitivity in Brazil.

A gradual reduction has been recorded for DMI (tebuconazole) effectiveness over the years of use in ASR control in Brazil. For example, the efficiency of rust control by tebuconazole was 90 and $91 \%$ in $2003 / 05$ season, $77 \%$ in $2005 / 06,58 \%$ in $2006 / 08,39 \%$ in $2008 / 09$ and only $24 \%$ in $2009 / 10(6,7)$. Will such reduction continue until $P p$ completely loses its sensitivity to DMIs?

The $\mathrm{IC}_{50}$ of tebuconazole, calculated by probit procedure, ranged from 0.11 to $5.102 \mathrm{mg} / \mathrm{L}$ and the sensitivity reduction factor, from 0.22 to 104.2. The hypothesis that the control failure occurring in soybean farms could be attributed to a decrease in the sensitivity of $P p$ isolates to the fungicide tebuconazole was confirmed. Eighty percent of $15 P p$ isolates showed reduced sensitivity to the fungicide tebuconazole $(1,9)$.

Thus, fungicide resistance has been a serious and intensively studied issue in the management of a large number of key fungal diseases affecting most crops. It threatens the commercial potential of chemicals, particularly those having a single-site mode of action such as DMI, QoI, and SDHI $(1,4,5,12)$.

Some strategies may contribute to reverse the reduction in $P p$ sensitivity to DMI, for example: Use fungicides with multi-site biochemical mechanism of action. Do not use alone or in mixtures two fungicides with specific site of action (e.g. DMI + QoI or QoI + SDHI), but use the multi-site fungicide for which there is less or no risk of fungus adaptation resulting in a resistant mutant (4). 
Fungicides of multi-site mode of action have the chance to be strong allies in the defense against soybean rust (8).

Addition of mancozeb to reinforce the fight against fungal resistance is not a new strategy. It has been included in mixtures to help resistance management and to broaden the spectrum of single-site fungicides. To stabilize ASR control, the same strategy used for a long time in potato/tomato mildew control could be used in soybean to chemically manage ASR. Examples of partners for mancozeb mixture include benalaxyl, cymoxanil, dimethomorph, famoxadone, fenamidone, folpet, fosetyl-aluminum, iprovalicarb, mandipropamid, metalaxyl, and zoxamide (8). Similarly, this could be followed in the control of ASR in Brazil and elsewhere. To reinforce the role of mancozeb in anti-resistance strategies, nearly five decades of use and continual development have led to records in over 70 crops and 400 different diseases (8).

\section{REFERENCES}

1. Blum, M.M.C. Sensitivity of Phakopsora pachyrhizi to fungicides. 2009. 174p.Doctoral in Plant Pathology. University of Passo Fundo.

2. Campbell C. L.; Madden, L V. Introduction to plant disease epidemiology. New York. John Wiley \& Sons, 1990.

3. Canteri, M. G.; Godoy, C. V. Escala diagramática para avaliação da severidade da ferrugem da soja. Summa Phytopathologica, Botucatu, v. 29, p. 89, 2003.

4. FRAC, 2012. Fungicide resistance action committee. Global Crop Protection Organization. Brussels. (www.gcpt.org/frac).

5. Fundação. Fundação MT em campo, Boletim informativo - Bimestral Fundação MT. Ano 5, nº 24 Abril/Maio, 2008
6. Godoy, C.V.; Palaver, L. Ensaio cooperativo para avaliação da eficiência de fungicida no controle da ferrugem da soja, em Londrina, PR, na safra 2010/11. In: Reunião de pesquisa de soja da região central do Brasil. 32., 2011, São Pedro. Resumos. São Pedro, 2011.

7. Godoy, C. V. et al. Eficiência de fungicidas para o controle da ferrugem-asiática da soja, Phakopsora pachyrhizi, na safra 2012/13: resultados sumarizados dos ensaios cooperativos. Londrina:2013 (Circular Técnica, 9a) PR. Setembro, 2013. $7 \mathrm{p}$.

8. Gullino, M.L.; Tinivella, F.; Garibaldi, A.; Kemmitt, G. M.; Bacci, L.; Sheppard, B. Mancozeb, past, present and future. Plant Disease, St. Paul, v. 94, n. 9, p:1076-1087. 2010

9. Reis, E.M.; Deuner, E. Zanatta, M. In vivo sensitivity reduction of Phakopsora pachyrhizi to tebuconazol. Summa Phytopathologica, Botucatu (in press), 2014.

10. Reunião de Pesquisa de Soja da Região Sul. Indicações técnicas para a cultura da soja no Rio Grande do Sul e em Santa Catarina, safras 2012/2013 e 2013/2014. / XXXIX Reunião de Pesquisa de Soja da Região Sul; organizada por Leila Maria Costamilan [et al.]. - Passo Fundo: Embrapa Trigo, 2012. 142 p.; - (Documentos / Embrapa Trigo, ISSN 1516-5582 ; 107). Realização da Embrapa Trigo e Apassul.

11. Russell, P. E. A century of fungicide evolution. Journal Agricultural Sciences. v.143, p. 11-25, 2005.

12 Schmitz, H. K.; Medeiros, C. A.; Craigc, I. R.; Stammlerd, G. Sensitivity of Phakopsora pachyrhizi towards quinone-outside-inhibitors and demethylation-inhibitors, and corresponding resistance mechanisms. Pest Managemente Science, 2013.

13. Silva, L.H.C.P.; Campos, H.D.; Silva, J.R.C.; Ribeiro, G.C.; Rocha, R.R.; Moraes, D.G. Eficácia reduzida de triazois no controle da ferrugem asiática. Fitopatologia Brasileira. Lavras, MG. v. 33, p.228, 2008 Suplemento.

14. Yorinori, J.T.; Paiva, W.M.; Frederick, R.D.; Fernadexez, P. F.T. Ferrugem da soja (Phakopsora pachyrhizi) no Brasil e no Paraguai, nas safras 2000/01 e 2001/02, p. 94. In: Resumos... II Congresso Brasileiro de Soja e Mercosoja 2002. Londrina: Embrapa Soja, 2002.393 p. (Documentos / Embrapa Soja; n. 181. Resumo 094). 